\title{
The mapping of a gene for craniosynostosis: evidence for linkage of the Saethre-Chotzen syndrome to distal chromosome $7 p$
}

\author{
L A Brueton, L van Herwerden, K A Chotai, R M Winter
}

\begin{abstract}
Craniosynostosis or premature closure of the cranial sutures is a common abnormality occurring in about 1 in 2500 children. There is evidence of mendelian inheritance in some $20 \%$ of cases. Published reports of patients with structural alterations of the short arm of chromosome 7 have suggested that two or more genes for craniosynostosis may be situated in this region. The Saethre-Chotzen syndrome (acrocephalosyndactyly type III) is one of the most common autosomal dominant craniosynostosis syndromes. Results of molecular genetic linkage studies provide evidence for localisation of the gene responsible to distal chromosome 7 p.

(f Med Genet 1992;29:681-5)
\end{abstract}

Craniosynostosis is a relatively common birth defect defined as premature closure of one or more of the cranial sutures. Many of those affected require major craniofacial surgery. The frequency of craniosynostosis has been estimated to be in the order of $0.4 / 1000$, that is, 1 in 2500 persons. ${ }^{1}$ Craniosynostosis may occur as an isolated abnormality or in association with other congenital anomalies as part of the various craniosynostosis syndromes. To date, more than 60 craniosynostosis syndromes have been described, over half having a monogenic aetiology. ${ }^{2}$ Although individually quite rare, these autosomal dominant syndromes provide a way of mapping genes that predispose to craniosynostosis. The acrocephalosyndactylies (ACS) comprise a clinically similar group among the autosomal dominant craniosynostosis syndromes, characterised by coronal craniosynostosis in association with distal limb anomalies, particularly syndactyly. In 1960, Blank $^{3}$ reviewed published reports and concluded that cases of acrocephalosyndactyly could be classified into two groups, typical and atypical forms. The typical form is Apert syndrome, the hallmark of which is interdigital osseous fusion of the distal phalanges with complete syndactyly. The second group, atypical non-Apert acrocephalosyndactyly, was thought to comprise a heterogeneous collection of disorders.
The following conditions are considered separate entities in McKusick's catalogue ACS I, Apert syndrome (McKusick No 10120); ACS III, Saethre-Chotzen syndrome (McKusick No 10140); ACS V, Pfeiffer syndrome (McKusick No 10160); acrocephalosyndactyly, Robinow-Sorauf type (McKusick No 18075); Jackson-Weiss syndrome (craniosynostosis, midfacial hypoplasia, and foot abnormalities) (McKusick No 12315). All of these proposed entities share many major features in common and diagnostic dilemmas continue to arise, single cases being particularly difficult to classify. Some authors, including Cohen, ${ }^{2}$ do not consider Robinow-Sorauf type acrocephalosyndactyly to be a distinct entity, but suggest it is a manifestation of the Saethre-Chotzen syndrome.

The Saethre-Chotzen syndrome appears to be relatively common among the craniosynostosis syndromes. The condition was first recognised by Saethre in $1931 .{ }^{5} \mathrm{He}$ described a hereditary disorder in a mother and two children consisting of craniosynostosis, low frontal hairline, facial asymmetry, deviation of the nasal septum, vertebral anomalies, brachydactyly, fifth finger clinodactyly, and syndactyly of the second and third fingers and second, third, and fourth toes. The following year Chotzen found identical malformations in a father and two sons. ${ }^{6}$ Many authors have subsequently reported affected families.

The most comprehensive review of the Saethre-Chotzen syndrome was by Pantke et $a l^{7}$ in 1975, who reported six affected families in detail. Many of the clinical findings in Saethre-Chotzen syndrome may be found in other craniosynostosis syndromes but the overall pattern of anomalies is distinctive and includes a high incidence of ptosis, tear duct anomalies, and low frontal hairline. Other helpful diagnostic features include palpable parietal foramina, abnormalities of the maxillary lateral incisors, and small ears with prominent crura. Inheritance is autosomal dominant with a wide range of expressivity.

We embarked on a study to determine the chromosomal localisation of the mutation(s) giving rise to the Saethre-Chotzen syndrome (ACS III) and related disorders as the first step towards identification of the gene defect(s).

Chromosome 7 was chosen as a suitable
Received 10 March 1992. Revised version accepted 21 May 1992. 
starting point for several reasons. Premature sutural fusion is a relatively uncommon finding in patients with chromosome anomalies but has been reported in at least 10 patients with a variety of structural alterations of $7 p$. The clinical features observed in several of these cases are reminiscent of the non-Apert acrocephalosyndactylies. Schomig-Spingler et $a l^{8}$ recorded craniosynostosis in association with a deletion of 7pter-p21 and summarised the findings in a total of 19 patients with $7 p$ deletions, seven of 19 having craniosynostosis. Although more than 20 cases of partial $7 p$ monosomy have been described, there is considerable cytogenetic heterogeneity regarding size and location of the deleted segments. However, craniosynostosis appears to be consistently associated with deletion of one of two specific and separate regions, either deletion of part of bands $7 \mathrm{p} 21 /$ proximal $7 \mathrm{p} 22$ or deletion of $7 \mathrm{p} 13-\mathrm{p} 14$. There have been only two reports of pure terminal $7 \mathrm{p} 22$ deletions ${ }^{910}$ and neither had craniosynostosis, suggesting that deletion

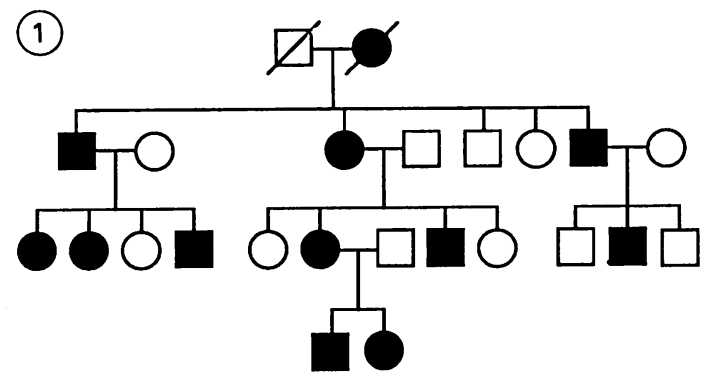

(2)

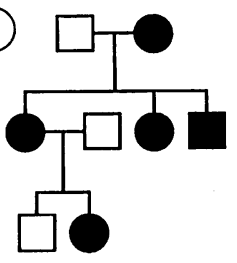

(3)

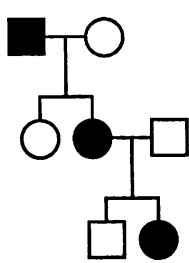

(4)
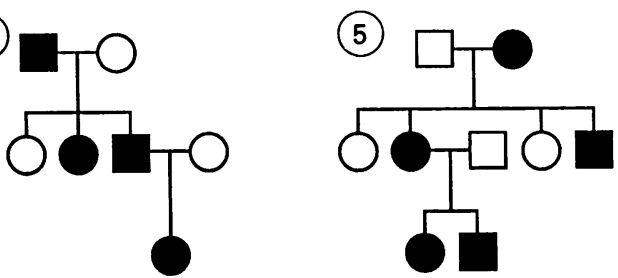
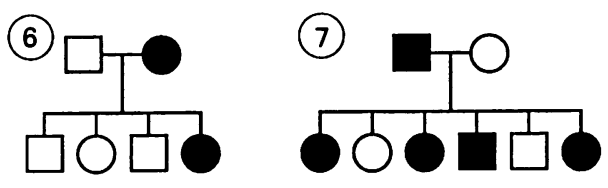

(8)
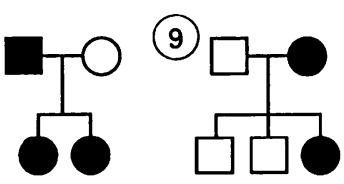

(10)
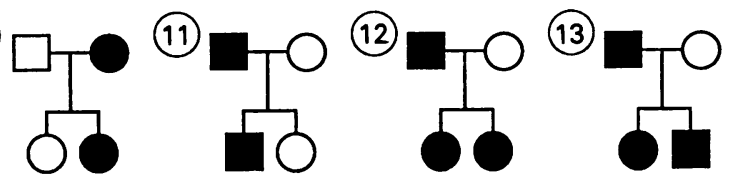

(16)
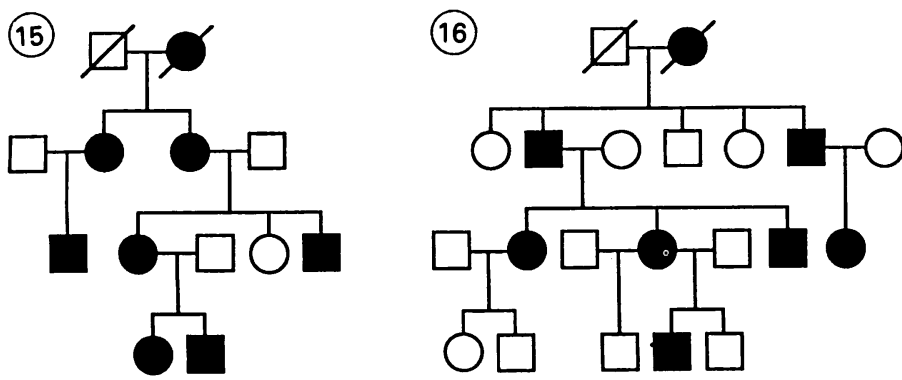

Figure 1 Pedigree structure of families used in the present study. of $7 \mathrm{p} 22$ is not necessarily associated with craniosynostosis. However, band 7 p21 was apparently cytogenetically intact in a case of ring chromosome 7 with craniosynostosis. ${ }^{11}$ Thus the critical segment for craniosynostosis on distal $7 p$ seems most likely to be located in distal band $7 \mathrm{p} 21$ or proximal $7 \mathrm{p} 22$.

The Greig cephalopolysyndactyly syndrome (GCPS) is an autosomal dominant disorder affecting limb and craniofacial development in man. ${ }^{12}$ Craniosynostosis is an occasional feature. The GCPS locus was localised to chromosome 7 p13 by two balanced translocations associated with GCPS in different families $^{1314}$ and subsequent demonstration of tight linkage of GCPS to the epidermal growth factor receptor (EGFR) gene $(7 \mathrm{p} 12-13) .{ }^{15} \mathrm{~A}$ further family with GCPS and a balanced translocation has recently been identified. ${ }^{16}$

As it seems that two or more genes for craniosynostosis may be situated on the short arm of chromosome 7 , we have undertaken linkage studies in a series of non-Apert acrocephalosyndactyly pedigrees using a panel of DNA probes spanning $7 p$ with the key areas of interest being $7 \mathrm{p} 13$ and $7 \mathrm{p} 21$.

\section{Materials and methods}

FAMILY MATERIAL

Clinical and molecular genetics studies were performed in 14 British families with apparent autosomal dominant non-Apert acrocephalosyndactyly to help define the degree of interand intrafamilial variability and address the question of whether abnormal genes at one or more loci cause these syndromes. Relevant family members were examined (by LB) and blood samples taken for analysis from 96 subjects, 47 of whom were affected. The outcome of the clinical study will be published in detail elsewhere.

Two of the families have been reported previously, family $1^{17}$ and family $16,{ }^{18}$ and having reviewed affected members in detail we are confident in classifying the former as having Saethre-Chotzen syndrome, while the latter most closely resembles the pedigree described by Jackson et al. ${ }^{19}$ Two further families were referred from abroad for inclusion in the linkage study. The pedigrees of the 16 study families are shown in fig 1 . Ten were classified as having classical Saethre-Chotzen syndrome, four a Saethre-Chotzen syndrome-like, nonApert acrocephalosyndactyly syndrome but without ptosis, parietal foramina, low frontal hairline, or lacrimal duct stenosis, one Jackson-Weiss type acrocephalosyndactyly (pedigree 16), and one family had a Pfeiffer-like syndrome (pedigree 15). There was no evidence of non-penetrance in obligate gene carriers.

\section{CHROMOSOME ANALYSIS}

Chromosome analysis ( $G$ banding of cultured lymphocytes) was performed on one affected subject from each family using standard techniques. In all cases the chromosomes were normal. 
Table 1 Details of probes and restriction enzymes used in this study.

\begin{tabular}{|c|c|c|c|c|c|}
\hline DNA probe & $\begin{array}{c}\text { HGM } \\
\text { symbol }\end{array}$ & $\begin{array}{c}\text { Cytogenetic } \\
\text { location }\end{array}$ & Enzyme & PIC & RFLP size (kb) \\
\hline $\begin{array}{l}\text { pHER-A64 } \\
\text { CRI-R944 } \\
\text { CRI-P137 } \\
\text { G-80 } \\
\text { pV11SPRS } \\
\text { G-98 } \\
\text { HOX1.4 } \\
\text { pB2.15 } \\
\text { pJ5.11 } \\
\text { pRMU7.4 } \\
\text { TS194 } \\
\text { TM102L } \\
\text { MS31 }\end{array}$ & $\begin{array}{l}E G F R \\
D 7 S 69 \\
D 7 S 65 \\
D 7 S 373 \\
T C R G \\
D 7 S 410 \\
D 7 S 441 \\
I L 6 \\
D 7 S 10 \\
D 7 S 370 \\
D 7 S 150 \\
D 7 S 135 \\
D 7 S 21\end{array}$ & $\begin{array}{l}\text { 7p12-p13 } \\
\text { 7p13 } \\
\text { 7p13 } \\
\text { 7p13-p15 } \\
\text { 7p14-p15 } \\
\text { 7p14-p21 } \\
\text { 7p14-p21 } \\
\text { 7p14-p21 } \\
\text { 7p14-pter } \\
\text { 7p14-pter } \\
\text { 7p15-pter } \\
\text { 7p15-pter } \\
\text { 7p22 }\end{array}$ & $\begin{array}{l}\text { StuI,XbaI } \\
\text { MspI } \\
\text { TaqI } \\
\text { TaqI } \\
\text { TaqI } \\
\text { TaqI } \\
\text { BglII } \\
\text { MspI,BglI } \\
\text { MspI } \\
\text { MspI } \\
\text { TaqI } \\
\text { TaqI } \\
\text { HinfI }\end{array}$ & $\begin{array}{l}0 \cdot 36 \\
0 \cdot 36 \\
0 \cdot 40 \\
0 \cdot 29 \\
0 \cdot 37 \\
0 \cdot 38 \\
0 \cdot 35 \\
0 \cdot 37 \\
0 \cdot 38 \\
0 \cdot 36 \\
0 \cdot 32 \\
0 \cdot 37 \\
0.99\end{array}$ & $\begin{array}{l}20 / 13 \cdot 7,12 / 10 \\
4 \cdot 0 / 3 \cdot 0 \\
3 \cdot 7 / 2 \cdot 7,1 \cdot 0 \\
7 \cdot 0 / 6 \cdot 5 \\
4 \cdot 1 / 3 \cdot 7 \\
0 \cdot 9 / 0 \cdot 8 \\
4 \cdot 3 / 3 \cdot 1,1 \cdot 2 \\
7 \cdot 5 / 4 \cdot 0,7 \cdot 6 / 5 \cdot 7 \\
5 \cdot 8 / 5 \cdot 5 \\
5 \cdot 5 / 2 \cdot 3 \\
1 \cdot 5 / 1 \cdot 0 \\
12 \cdot 0 / 8 \cdot 5 \\
\text { Many }\end{array}$ \\
\hline
\end{tabular}

CHROMOSOME 7 PROBES

The chromosome 7 specific probes used, including both cloned human genes and randomly generated DNA segments, are listed in table 1 along with restriction fragment length polymorphisms (RFLP) and locations. Markers pJ5.11 (D7S10), pBeta2.15 (IL6), G98 (D7S410), and G80 (D7S373) were kindly provided by Drs J Schmidtke, P B Sehgal, and G Camerino respectively. pRMU7.4 (D7S370), TM102L (D7S135), TS194 (D7S150), PVII SPRS (TCRG), and lambda pHER A64 $(E G F R)$ were obtained from ATCC, and CRI137 (D7S65) and CRI-R944 (D7S69) from Collaborative Research Incorporated.

DNA ANALYSIS

Genomic DNA was isolated from lymphocytes by standard techniques and $5 \mu \mathrm{g}$ was digested with the restriction endonuclease determining the polymorphic characteristic of the specific probe. ${ }^{20}$ The resulting fragments were separated by electrophoresis on a $0.8 \%$ agarose gel and transferred to a nylon membrane (Hybond-N, Amersham PLC) by Southern blotting. ${ }^{21}$ The probes were labelled with ${ }^{32} \mathrm{P}$ dCTP by random oligonucleotide primed synthesis of the probe insert. ${ }^{22}$ Hybridisation conditions were as described by Maniatis et al, ${ }^{20}$ and washing was performed at $65^{\circ} \mathrm{C}$ in $2 \times$ SSC.
LINKAGE ANALYSIS

Two point linkage analysis and multipoint likelihood calculations were computed using the LINKAGE program package ${ }^{23}$ assuming complete penetrance at the disease locus with a gene frequency of 1 in 40000 . A lod score of at least 3 was considered evidence of genetic linkage, and the lod score of -2.0 taken as an exclusion boundary. The families were analysed initially as a group and then with the two non-ACS III-like pedigrees (15 and 16) excluded.

\section{Results}

Pairwise lod scores for equal male and female recombination fractions for all families between $A C S$ and each of the chromosome 7 markers are shown in table $2 . A C S$ was clearly not linked to markers from proximal $7 \mathrm{p}$ in the vicinity of the Greig cephalopolysyndactyly syndrome locus. However, results obtained with two of the more distal markers, pRMU7.4 (D7S370) $)^{24}$ and pJ5.11 (D7S10), ${ }^{25}$ show evidence for linkage to the putative $A C S$ locus. The highest two point value was for pJ5.11 with a maximum lod score of 3.35 at $\theta=0$ when all the family data were analysed together. Tight linkage to $\mathrm{p} \beta 2.15, \mathrm{TS} 194$, and TM102L was excluded; however, the exclusion limits are narrow. There was no evidence for linkage to HOX1.4 or MS31. Pedigree 15

Table 2 Pairwise lod scores between ACS III and $7 p$ marker loci.

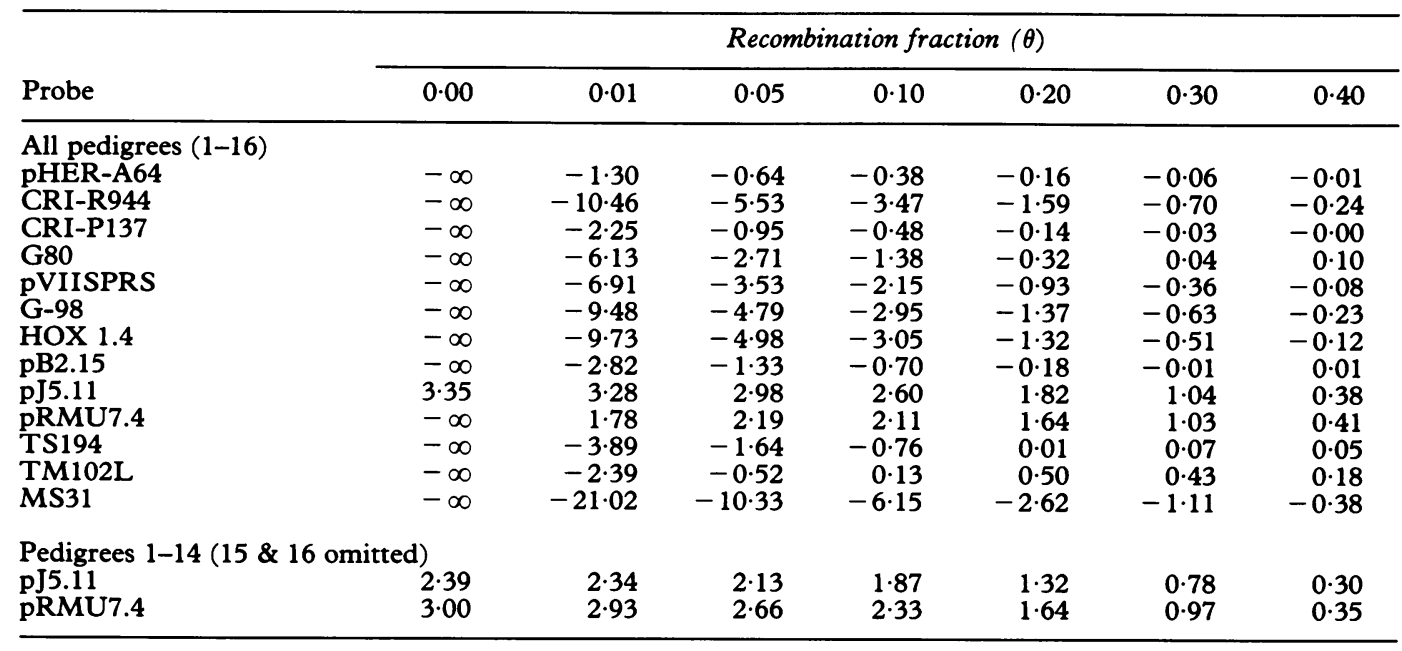


with possible Pfeiffer syndrome was uninformative for pJ5.11 and pRMU7.4 and showed no linkage to other $7 \mathrm{p}$ markers. Pedigree 16 showed the only recombination between the disease locus and pRMU7.4, but there was no recombination with $\mathrm{pJ} 5.11(\operatorname{lod}=0.9$ at $\theta=0)$. There was no linkage to other $7 p$ markers in this family. This pedigree more closely resembles the Jackson-Weiss syndrome. Given the possibility of heterogeneity, the data were reanalysed with pedigrees 15 and 16 excluded and a maximum lod score of 3.00 obtained with pRMU7.4 at $\theta=0$, the two point value for pJ5.11 being 2.39 at $\theta=0$. The data generated a lod score of 1.23 , with no recombination events observed between probes pJ5.11 and pRMU7.4. There was no evidence for close linkage of either probe to any of the other DNA markers used in this study. Recent data have suggested that $\mathrm{pJ} 5.11$ (D7S10) and pRMU7.4 (D7S370) flank TM102L (D7S135), with pJ5.11 being distal. ${ }^{26}$ Multipoint analysis using LINKMAP setting pJ5.11 and TM102L $10 \mathrm{cM}$ apart and 102L and pRMU7.4 $18 \mathrm{cM}$ apart $^{26}$ is shown in fig 2, using all 16 families.

\section{Discussion}

The results of linkage analysis support localisation of a non-Apert ACS locus to the distal short arm of chromosome 7 in the $7 \mathrm{p} 21$ region, showing significant lod scores for pRMU7.4 and pJ5.11 with or without inclusion of pedigrees 15 and 16 . It is not yet certain whether the non-Apert ACS syndromes are allelic. The only recombinant in this study with the linked probes involved pRMU7.4 in family 16 which resembled Jackson-Weiss syndrome. The one Pfeiffer-like pedigree was largely uninformative. All the other pedigrees would fit with

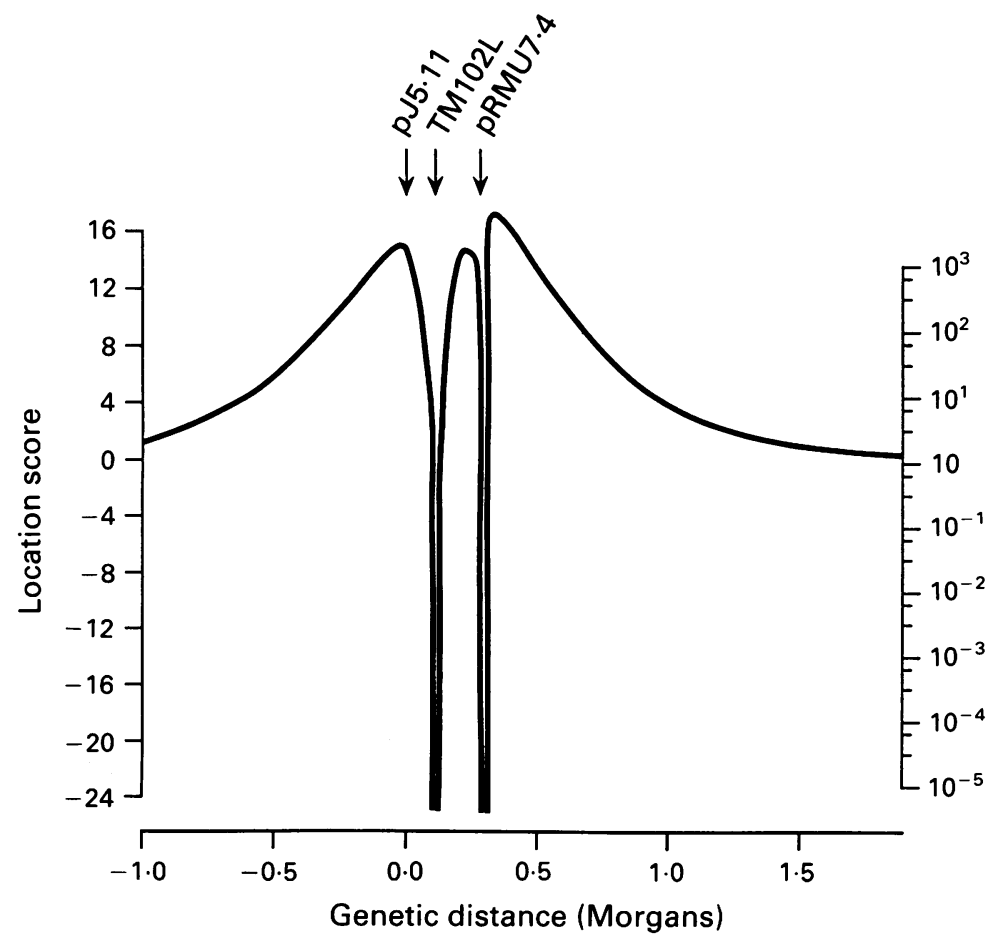

Figure 2 Multipoint linkage analysis. See text for details of marker order. a diagnosis of Saethre-Chotzen syndrome (ACS III) and there was no evidence of linkage heterogeneity in these families. Multipoint linkage analysis would favour the ACS gene being proximal to pRMU7.4 (D7S370) but this localisation is not precise.

The localisation, identification, and characterisation of one or more of the genes predisposing to craniosynostosis will lead to determination of the genetic elements involved in the complex process of normal skull development and the consequences of mutations in these developmental genes.

Recently two out of three balanced translocations reported to segregate with the Greig cephalopolysyndactyly syndrome have been shown to interrupt the GLI3 gene, ${ }^{27}$ a zinc finger gene, previously localised to $7 \mathrm{p} 13 .{ }^{28}$ Various zinc finger proteins are known to have key roles in Drosophila development, ${ }^{29}$ and so it is quite possible that they are also similarly important in humans. Of other genes mapping to $7 \mathrm{p}$, the homeobox gene Hox $1.4,{ }^{30}$ and $\mathrm{KOX}^{31}$ (another zinc finger gene) could also be considered potential candidate genes for human craniodigital syndromes. Molecular genetic analysis of a panel of $7 p$ deletions associated with craniosynostosis (unpublished observation) and linkage data presented here provide evidence that Hoxl.4 is not implicated, and the role of $\mathrm{KOX} 3$ is currently under study.

We would like to thank Drs Michael Baraitser, Robin Clark, Albert Schinzel, Ian Young, Susan Huson, and Mr Michael Poole for referring families and providing specimens.

1 Hunter AGW, Rudd NL. Craniosynostosis I. Its genetics and associated clinical findings in 214 patients who lacked involvement of the coronal suture. Teratology 1976; 14:185-93.

2 Cohen MM Jr. Syndromes with craniosynostosis. In: Cohen MM, ed. Craniosynostosis: diagnosis, evaluation and management. New York: Raven Press, 1986:413-590.

3 Blank CE. Apert's syndrome (a type of acrocephalosyndactyly); observations on a British series of thirty nine cases. Ann Hum Genet 1960;24:151-64.

4 McKusick VA. Mendelian inheritance in man. 8 th ed. Baltimore: Johns Hopkins University Press, 1988.

5 Saethre H. Ein Beitrag zum Turmschadelproblem. (Pathogenese, Erblichkeit und Symptomologie). Dtsch Z Nervenheilkd 1931;117:533-55.

6 Chotzen F. Eine eigenartige familiare Entwicklungsstörung. (Akrocephalosyndaktylie, Dysostosis craniofacialis ung. (Akrocephalosyndaktylie, Dysostosis craniofacialis 55:97-122.

7 Pantke OA, Cohen MM Jr, Witkop CJ, et al. The SaethreChotzen syndrome. Birth Defects 1975;11(2):190-225.

8 Schomig-Spingler N, Schmid M, Brosi W, Grimm T Chromosome 7 short arm deletion, 7p21-pter. Hum Gene 1986;74:323-5.

9 Speleman F, Craen M, Leroy J. De novo terminal deletion 7 p22.1-pter in a child without craniosynostosis. $\mathcal{f} \mathrm{Med}$ Genet 1989;26:528-32.

10 Baccichetti C, Artifoni L, Zanardo V. Deletions of the shor arm of chromosome 7 without craniosynostosis. Clin Genet 1982;21:348-9.

11 Zackai EH, Breg WR. Ring chromosome 7 with variable phenotypic expression. Cytogenet Cell Genet 1973;12:408.

12 Greig DM. Oxycephaly. Edinburgh Med f 1926;33:198-218.

13 Tommerup N, Nielsen $F$. A familial reciprocal translocation $t(3 ; 7)(p 21.1 ; 13)$ associated with the Greig polysyndact dactyly-craniofacial

14 Pelz L, Kruger G, Gotz I. The Greig cephalopolysyndactyly syndrome. Helv Paediatr Acta 1986;41:381.

15 Brueton J, Huson SM, Winter RM, Williamson R. The chromosomal localisation of a developmental gene in man. chromosomal localisation of a developmental gene in man. Direct DNA analysis demonstrates that Greig cephalo-
polysyndactyly (GCPS) maps to $7 \mathrm{p} 13$. Am $\mathcal{F}$ Med Genet 1988;31:799-804.

16 Vortkamp A, Thias U, Gessler M, et al. A somatic cell hybrid panel and DNA probes for physical mapping of human chromosome 7p. Genomics 1991;11:737-43. 
17 Young I, Harper PS. An unusual form of familial acrocephalosyndactyly. $\mathcal{F}$ Med Genet 1982;19:286-8.

18 Baraitser M. Pitfalls of genetic counselling in Pfeiffer's syndrome. F Med Genet 1980;17:250-6.

19 Jackson CE, Weiss L, Reynolds WA, et al. Craniosynostosis, mid-facial hypoplasia and foot abnormalities: an autosomal dominant phenotype in a large Amish kindred. $\mathfrak{f}$ Pediatr 1976;88:963-8.

20 Maniatis T, Fritsch EF, Sambrook J. Molecular cloning: a laboratory manual. Cold Spring Harbor, New York: Cold Spring Harbor Laboratory, 1982.

21 Southern $M$. Detection of specific sequences among DNA fragments separated by gel electrophoresis. $7 \mathrm{Mol} \mathrm{Biol}$ fragments separate

22 Feinberg AP, Vogelstein B. Addendum. A technique for radiolabeling DNA fragments to high specific activity. Anal Biochem 1984:137.266-7.

23 Lathrop GM, Lalouel JM, Julier C, Ott J. Strategies for multilocus analysis in humans. Proc Natl Acad Sci USA 1984;81:3443-6.

24 Myers R, Nakamura Y, Gillilan S, et al. Isolation and mapping of a polymorphic DNA sequence (pRMU7.4) on chromosome 7p (D7S370). Nucleic Acids Res 1988;16:3591.
25 Cooper DN, Smith BA, Cooke HJ, et al. An estimate of unique DNA sequence heterozygosity in the human genome. Hum Genet 1985;69:201-5.

26 Chotai KA, Brueton LB, Van Herwerden L, et al. Six cases of $7 p$ deletion: clinical features, cytogenetic findings and molecular studies. Am $\mathcal{F}$ Hum Genet (submitted).

27 Vortkamp A, Gessler M, Grzeschik K-H. GLI3 zinc finger gene interrupted by translocations in Greig syndrome gene interrupted by translocation

28 Ruppert JM, Vogelstein B, Arheden K, Kinzler KW. GLI3 encodes a 190 kilodalton protein with multiple regions of GLI similarity. Mol Cell Biol 1990;10:5408-15.

29 Preiss A, Rosenberg VB, Keinlin A, et al. Molecular genetics of Kruppel, a gene required for segmentation of the Drosophila embryo. Nature 1985;313:27-32.

30 Ferguson-Smith AC, Feinberg A, Ruddle FH. Isolation, chromosomal localization and nucleotide sequence of the human Hox 1.4 homeobox. Genomics 1989;5:250-8.

31 Seite $\mathrm{P}$, Huebner K, Rousseau-Merck MF, et al. Two human genes encoding zinc finger proteins, ZNF12 human genes encoding zinc finger proteins, ZNF12 7p22-21 and 12q24-33 respectively. Hum Genet 1991; 86:585-90. 